\title{
François Rouget, Marguerite de Valois en son temps: nouveaux documents sur les affaires de la reine Margot
}

\section{Filippo Fassina}

\section{(2) OpenEdition}

1 Journals

\section{Edizione digitale}

URL: http://journals.openedition.org/studifrancesi/9844

DOI: $10.4000 /$ studifrancesi. 9844

ISSN: 2421-5856

\section{Editore}

Rosenberg \& Sellier

\section{Edizione cartacea}

Data di pubblicazione: 1 octobre 2007

Paginazione: 430

ISSN: 0039-2944

\section{Notizia bibliografica digitale}

Filippo Fassina, «François Rouget, Marguerite de Valois en son temps: nouveaux documents sur les affaires de la reine Margot», Studi Francesi [Online], 152 (LI | II) | 2007, online dal 30 novembre 2015, consultato il 08 janvier 2021. URL: http://journals.openedition.org/studifrancesi/9844 ; DOI: https:// doi.org/ERREUR PDO dans /localdata/www-bin/Core/Core/Db/Db.class.php L.34 : SQLSTATE[HY000] [2006] MySQL server has gone away

Questo documento è stato generato automaticamente il 8 janvier 2021.

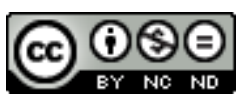

Studi Francesi è distribuita con Licenza Creative Commons Attribuzione - Non commerciale - Non opere derivate 4.0 Internazionale. 


\title{
François Rouget, Marguerite de Valois en son temps: nouveaux documents sur les affaires de la reine Margot
}

\author{
Filippo Fassina
}

\section{NOTIZIA}

FRANÇOIS ROUGET, Marguerite de Valois en son temps: nouveaux documents sur les affaires de la reine Margot, «Bibliothèque d'Humanisme et Renaissance», LXVIII, 1 (2006), pp. 109-114.

1 Il breve articolo ha per oggetto una parte inedita della corrispodenza di Marguerite de Valois, moglie del re di Navarra. Il materiale qui esaminato riguarda lettere private e atti notarili. Le lettere premettono di comprendere meglio le relazioni private, ma anche gli affaires politici e religiosi della regina, mentre gli atti mettono in luce l'interesse di Marguerite de Valois per l'amministrazione dei propri beni, soprattutto durante e dopo la difficile esperienza dell'esilio forzato a Carlat. 